\title{
Critical Study of Research Results about TVET and Tefa's Role in Social, Economic and Education Development in The Country
}

\author{
S Muslim ${ }^{1}$, E Ismayati ${ }^{2}$, N Kusumawati ${ }^{3}$, E Rahmadyanti ${ }^{4}$, M A Hilmi ${ }^{5}$, A Ciptono ${ }^{6}$, S \\ Setiyono ${ }^{7}$, D Lukmantoro ${ }^{8}$ \\ \{ supari@unesa.ac.id ${ }^{1}$, Euisheru@gmail.com ${ }^{2}$, nitakusumawati99@gmail.com ${ }^{3}$, \\ erinarahmadyanti@unesa.ac.id ${ }^{4}$, alfin.hilmi@gmail.com ${ }^{5}$, argo.ciptono@gmail.com ${ }^{6}$, \\ kislamet@gmail.com ${ }^{7}$,dhanu@gmail.com ${ }^{8}$ \}
}

\author{
Electrical Engineering of Education,Universitas Negeri Surabaya, Indonesia ${ }^{1,2}$ \\ Chemistry of Department,Universitas Negeri Surabaya, Indonesia ${ }^{3}$ \\ Civil Engineering of Department,Universitas Negeri Surabaya, Indonesia ${ }^{4}$ \\ Vocational Education,Universiti Tun Hussien Onn Malaysia, Indonesia ${ }^{5,6,7,8}$
}

\begin{abstract}
TVET has a strategic role. What is TEFA? What is the effect of TEFA on the work readiness of vocational students? Does the application of TEFA contribute to the economic development and education of a country? The purpose of this study was to determine the role of TVET and TEVA on social, economic and educational development in a country. The study conducted a literature review method on a number of references and relevant research results, and Focus Group Disscussion (FGD). The study found: (1) TVET has a key and key role in the social, economic and educational fields of a country; (2) the impact of TVET in Nigeria and other developing countries, has not been impressive; (3) the application of TEFA has a positive and significant effect on work readiness of vocational students; and (4) the application of TEFA contributes to the social, economic and educational development of a country.
\end{abstract}

Keywords: TVET, TEVA, Social, Economy and Education, Country.

\section{Introduction}

UNEVOC as a policy implementing agency from the United Nations (UN) has placed a strategic role in vocational education and training (TVET), especially for developing countries. UNEVOC has been trying to realize TVET as vocational education and training involving general education, technology studies, and related sciences, to acquire practical skills, attitudes, and knowledge related to employment in all sectors of the economy and social life. Therefore TVET needs to be understood as: (1) an integral part of general education; (2) means to prepare the field of work and participation in the world of work; (3) media of lifelong learning and preparation as responsible citizens; (4) developing instruments to promote environmental insight in a sustainable manner; and (5) methods to facilitate poverty alleviation. Vocational education and training (TVET) refer to (1) education and training that prepares students for employment; and (2) learning that will make students more productive in certain economic fields. It is reasonable, presumably the benefits of TVET need to be distributed more evenly between men and women, as well as between rural and urban areas. Thus, vocational 
education and training (TVET) have a vital role in the social field and economic development of a nation, because TVET is able to develop and produce skilled resources in the industry, and is able to play a role and facilitate poverty alleviation programs.

TVET's strategic role according to Sudira (2018: 3) is: (1) transforming knowledge, technology, art, new skills, culture, and work character; (2) increasing the ability and willingness of the community to contribute to work; (3) train and develop the potential of themselves and their children to have life skills and skills in a productive career; (4) developing self-responsibility as citizens in realizing unity, prosperity, social justice, and national competitiveness; (5) cultivating compulsory lifelong learning as a process of developing self capacity in the context of economic strengthening, social cohesion, and national dignity; (6) carry out the conservation of the noble culture and the environment as the inheritance of the nation's children; and (7) improve physical, mental and spiritual health.In line with this strategic role, TVET curriculum and learning need to be designed so as to provide assurance for every graduate to enter the workforce and his career develops in the future. TVET's success is measured from four aspects (Sudira, 2018: 6) which include: (1) the level of absorption of graduates in the workforce: (2) the level of alumni satisfaction after graduation; (3) the level of user satisfaction on the performance of alumni; and (4) the number of alumni who become entrepreneurs. Therefore mastery of competencies that includes a number of skills and work knowledge as a learning experience, must be used effectively in schools, communities and the world of work. This is the real impact of TVET. Question: Has the application of TVET contributed to the development of a country's social, economic and educational fields? What is the impact of TVET in developing countries?

To support the strategic role of TVET, there are many programs that need to be done including the use of learning models that are in accordance with the characteristics of subjects in the TVET environment, including vocational schools. There are many learning models, including direct learning models, base learning problems, cooperative learning, project-based learning, teaching factories, and others. The implementation of the teaching factory (TEFA) is related to three main factors, namely: (1) ordinary learning, considered insufficient; (2) student competence is derived from direct practical experience; and (3) team-based learning involving students, teaching staff and industrial technicians who will enrich the educational process and benefit many parties [1]. The basic principle of TEFA is the integration of work experience into the school curriculum, where equipment, materials and teaching staff are designed to carry out the process of producing goods/services [1]. The benefits of TEFA activities can add to the source of school income for educational activities. TEFA model learning presents a real-world of industry in the school environment, to prepare graduates who are ready to work as described by [2] as shown in Figure 1.a which is equipped with a schedule as shown in Figure 1.b below this. 


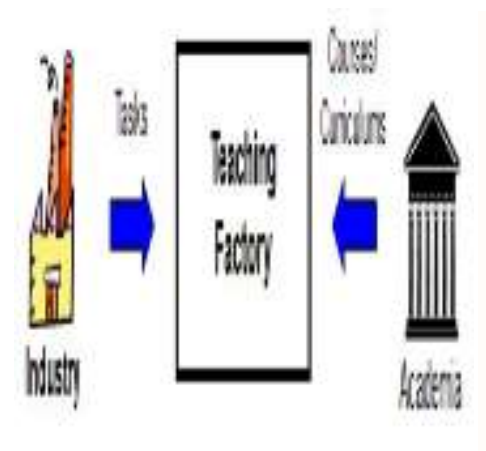

a)

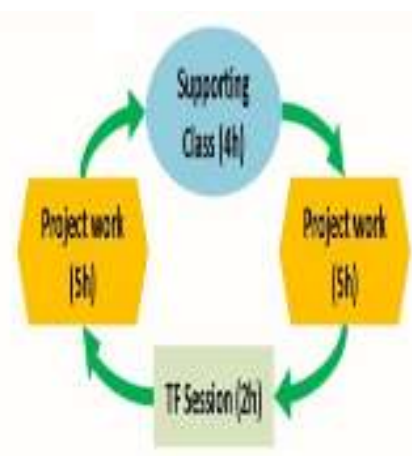

b)

Figure. 1. Concepts and Schedule of Teaching Factory Activities

(Source: Rentzos L.A, et al., 2014)

In TEFA, there are interactions between teachers, industrial technicians, and students who learn by using tools, instruments, procedures and work methods in the industry in a real way, in the activities of producing goods/services that are worth selling on industry product standards. To obtain optimal learning outcomes for students, as well as goods/services according to industry standards, TEFA activities can be carried out with a learning schedule as shown in Figure 1.b above. While Alptekin, et al. (2001), describes TEFA as shown in Figure 2, wherein TEFA of Cal Poly, there are at least 5 (five) divisions [3], namely: (1) Industrial Partners; (2) Production Planning and Control Center; (3) CAD Laboratories; (4) Rapid Prototyping Manufacturing Facilities; and (5) students. TEFA of Cal Poly has a lot of support from the industry so that the implementation of TEFA can run optimally.

The Division of Production Planning and Control Center is a division that serves as a production planner and quality control. CAD Laboratories Division is a division that carries out testing of the planning results of the Production Planning and Control Center Division, so that the development of goods/services products designed and developed, the quality is always well controlled. Whereas the Division of Rapid Prototyping Manufacturing Facilities is a division that is in charge of making prototypes of goods and or service products that have been developed by the Division of Production Planning and Control Center and has been properly and properly tested by the Division of CAD Laboratories. With the organization structure, management, and implementation of the TEFA, TEFA of Cal Poly is expected to be able to run, function and be useful as a place of learning for students, in accordance with the existing curriculum, as well as producing goods / services that are worth selling with goods industry standards/services in general.

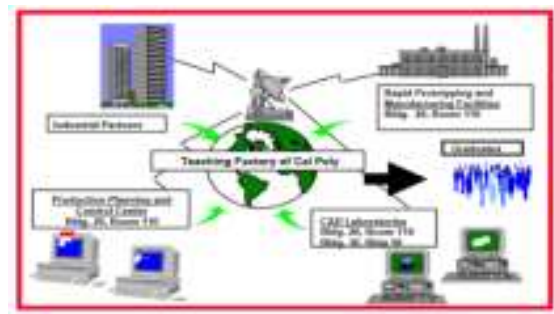

Figure 2. Teaching Factory of Cal Poly (Source: Alptekin, S.E. et al., 2001) 
The purpose of TEFA[1]) is: (1) to practice soft skills in learning; (2) learning and working in teams; (3) practice interpersonal communication skills; (4) obtain hands-on experience and work practice. Whereas according to the Directorate of Vocational Development (2015) the objectives of TEFA are: (1) preparing students to become prospective workers; (2) preparing students to study to a higher level; (3) help students choose work fields according to their abilities; (4) shows that learning by doing is important for the growth of education creativity and effectiveness; (5) witness the skills needed in the world of work; (6) expanding opportunities for recruitment for students; (7) improve student work readiness; (8) establish cooperation with the world of work; (9) train students to make career decisions to be chosen; (10) opportunities for teachers to build an "instructional bridge" between class and the world of work; (11) broadening teachers' insight into instructional matters; and (12) make students more active in learning, to achieve better achievements.

The TEFA implementation indicators according to the Directorate of Vocational Development (2015) include: (1) skills learning processes designed and implemented based on actual procedures and working standards; (2) learning settings are made as closely as possible with real work situations; (3) problem solving oriented; (4) is student active learning, independent learning and collaboration; (5) learning by learning by doing; (6) emphasizing the achievement of student competencies (individually and classically) according to work standards; (7) developing student soft skills (intellectual, emotional, spiritual / social intelligence); (8) learning to be responsible in the world of work, communicate, build commitment and creativity; (9) train students to continue to learn \& adapt to new knowledge; (10) develop and implement sustainable business-based learning patterns; (11) organizing and preparing students involved; (12) provide guidance/consultation to students individually and in teams; and (13) carry out evaluation and improvement of learning outcomes on an ongoing basis. Question: What is TEFA? What is the effect of TEFA on the work readiness of vocational students? Has TEFA been implemented properly? Is the application of TEFA able to contribute to the social, economic and educational development of a country? To answer a number of questions, it is necessary to conduct research with the title "A critical study of the results of research on the role of TVET and TEFA in social, economic and educational development in a country.

\section{Method}

The study was conducted using a literature review of a number of references and relevant research results of European countries, the United States (US), Africa and Asia, especially in Indonesia. The results of the study obtained were presented in the Focus Group Discussion (FGD) to obtain input and criticism in order to improve the results of the research.

\section{Result and Discussion}

There are many studies that want to reveal about TVET, and TEFA, both from the aspects of planning, implementation, and its influence on the work readiness of vocational students, their role in building economic growth and about evaluating the implementation of TVET or TEFA itself. [2] conducted a study entitled "Strategy to revitalize technical and vocational education and training (TVET), management perspectives" which concluded that: (1) TVET management seems to be more successful by considering the criteria of relevance to the labor market (which meets the needs of providers work and hope); and (2) access for trainees, 
quality of delivery, standardization, inclusion of soft skills, and funding for the system will be safer and uninterrupted; and (3) TVET education systems can be adapted from certain countries. The results of this study indicate that TVET management needs to pay attention to the expectations and needs of employers (the world of work / industry), so that: (1) there is a high level of absorption of TVET graduates including vocational graduates; (2) there is no waste on the education system in TVET because the need for a re-training level for prospective workers based on the needs of the workforce / industry becomes smaller. This is in line with the 16 Prosser propositions [3], where: (1) vocational education will be effective, if the environment in which students are trained is a replica of the environment in which they will work; (2) vocational education will be effective, only if the training tasks are carried out in the same way, tools and machines as specified in the workplace; and (3) vocational education will be effective if it trains someone in the habit of thinking and working, as needed in the world of work. On the other hand, if a country does not have a good TVET education system, it can adopt the TVET education system from other more advanced countries.

Furthermore, how far has TVET had an impact on national development? [4] reported the results of their research under the title "Impact of quality assurance (QA) on technical vocational education and training in Nigeria", which found that: (1) the impact of TVET in Nigeria was not impressive because QA was not effective at all levels of management; (2) TVET will have an impact on technical progress, work feasibility, and national development; (3) there is a need for policymakers to focus on important areas such as finance, access / participation, guaranteeing the quality and relevance of the program to the needs of the country. The results of this study indicate that QA in the TVET environment in general still needs to be improved, especially in Nigeria or other developing countries, because TVET is proven to have an impact on the national development of the country concerned. Therefore, [5] provide advice through research entitled "Challenges and improvement strategies", which concludes that: (1) adequate TVET funding is needed; (2) training and retraining of TVET teachers; (3) provision of TVET facilities needed; (4) adequate internal and external supervision; (5) public and private partnerships are an improvement strategy for quality TVET programs in Nigeria; and (6) recommended to governments, stakeholders, policymakers and TVET providers in Nigeria, should focus on TVET quality assurance best practices that have worked in countries around the world.On the other hand, especially related to the response of teachers and students to the role of TVET, Sidek (2007) reported the results of his research entitled "The role of TVET teachers in school-based assessment of vocational electives subjects at Dato Onn Batu Pahat Johor Middle School" concluded that: (1) the opinions of teachers and students on the suitability of PBS implementation in schools are in the high category; (2) the implementation of PBS in the rank of PMR and SPM is in the appropriate category; and (3) there is a high understanding of the implementation of PBS among teachers and students at the Dato Onn Batu Pahat National Middle School, Johor Malaysia.

While research that wants to reveal about the TEFA management model, among others, is carried out by [6] with the title "Management model of TEFA vocational high school", which concludes that: (1) factory management learning models can be applied in TEFA learning; (2) the factory management learning model can serve as a guide for TEFA managers (principals, teachers, industry partners); and (3) factory management learning models can produce constructive contributions in partnerships between vocational schools and industry. The results of this study are supported by the findings of [7] through research entitled "Development of teaching factory models in vocational schools", which concluded that: (1) TEFA management includes planning, organizing, implementing, and evaluating; (2) TEFA management developed for student practice, should be integrated with the production unit; and (3) the 
TEFA model is one of the solutions to prepare students to have competencies that are in accordance with the needs of the industrial world. The results of this study indicate that the implementation of TEFA needs to be carried out through good governance, including managers, implementers, facilities, planning, implementing organizations and evaluations. Good governance will have a positive impact on the success of TEFA implementation. While how far does the implementation of TEFA have an impact on the level of work readiness of vocational students? [8] reported the results of her research through a journal entitled "The factory contribution of teaching program implementation on work readiness of vocational high school students in Makassar" which concluded that: (1) there was a significant influence between the contribution of TEFA program implementation to readiness work of vocational students in Makassar with a contribution of 34.6\%; (2) the implementation of TEFA learning in vocational schools must be optimal to improve the work readiness of vocational students, so that the level of absorption of vocational school graduates becomes increased. The results of this study indicate that the level of work readiness of vocational students can be improved through learning TEFA models, even the application of TEFA contributes $34.6 \%$ to the level of work readiness. Through TEFA: (1) students will learn while working (learning by doing); (2) students will learn in groups and collaborate; and (3) students directly witness the benefits of the field of study being studied, which in turn will increase their motivation for learning. Through TEFA, students will learn while working in groups, so that there will be intellectual, skill, ethical and social development in each student [9]. Learning in the real world like that, will give students the opportunity to actively search for and combine information from work, society, or classrooms, then use it positively, will embed information in their memories [10]. Working while learning that emphasizes action, will give the brain the opportunity to feel the outside world in countless ways [10], so students will be better prepared to enter the world of work.

The research results of [8] above are in line with the findings of several other studies that the TEFA-6M model can: (1) improve student competence; (2) increasing student motivation in learning; (3) increasing student learning time in the workplace; (4) improving soft and hard skills; and (5) increasing sense of responsibility and ethics in work. Soft skills and hard, as well as learning ethics and responsibility in learning and working through the TEFA-6M model, in line with national education goals that want to create intelligent, skilled human resources and noble character. Such learning will create intelligent human resources in accordance with the demands of life in the 21 st century which must have the ability to think critically, innovatively, and have collaborative abilities supported by communication skills. Through TEFA, students learn with the right media, so that their skills will improve, both for students who have high or low levels of creative thinking. [11] found that there was a very significant interaction between the level of creative thinking and student learning media, towards the psychomotor domains learning outcomes. The results of this study indicate that learning media have an important influence on student learning outcomes. Working on training tools allows students to acquire practical knowledge and skills and then use those skills for problem solving and machine control [12] Especially in TEFA-based learning, there are group assignments, where students need discussion. Such group discussions, require an attitude of cooperation, sharing tasks and responsibilities in completing tasks [13]. Collaboration can eliminate mental barriers due to the limited experience and perspective [10].

The research findings of [9] above are also supported by research conclusions from [14], through research entitled "Management of TEFA implementation in order to prepare graduates to enter the workforce of Muhammadiyah 7 Gondanglegi Vocational School students" found: ( 1) from the aspects of preparation, implementation and evaluation activities of TEFA at 
Muhammadiyah 7 Gondanglegi Vocational School, it has been going well; and (2) through TEFA, Vocational students are better prepared to enter the world of work. The results of this study are in line with the findings of [15] through his research entitled "Increasing the achievement of the quality of D-3 electrical engineering graduates with the TEFA model" which concluded that: (1) the application of the TEFA model starting from competency standards, media, lecturers, students, the use and maintenance of the production, marketing and evaluation processes, has been structured quite well; (2) there are shortcomings in management aspects, so that TEFA does not reach the expected optimum point; and (3) however, there is a satisfactory increase in the quality of graduates of the D-3 electrical engineering program at the University of PGRI Kediri.Somewhat different from several studies on TEFA described above, Wafroturrohmah conducted a study entitled "Efforts to improve life skills and entrepreneurial values through TEFA learning in the millennium era" which concluded that TEFA learning was integrated with discovery learning, problem-based learning, and project-based learning, can improve personal life skills (personal skills, social skills, academic skills, and vocational skills) that are characterized by entrepreneurial values that include independent, creative, innovative, risk-taking, action-oriented, leadership, work hard and have competitiveness.

Furthermore, how far is the application of TEFA able to contribute to the economic development of a country? According to an IMF (International Monetary Fund) survey in April 2013, in Europe alone, manufactured products accounted for more than $28 \%$ of GDP, even though there was a recession. Therefore Manufuture's High-Level Group and Implementation Support Group (2006) suggested the need for promotion of superior manufacturing education (TEFA). Through TEFA, there will be a merger between the academic world and real practice, which will spur students' ability to think critically. The notion of society that critical thinking is only in the "philosophy course" is something wrong. It should be noted that critical thinking is not something that is difficult, which can only be done by those who have a high IQ in the genius category, whereas critical thinking is something that can be done by everyone [10], including vocational students. With these reasons, the habit of critical thinking must be instilled early on to the students. In line with [10], that training for critical thinkers is as important as practicing for tennis players and musicians, and it is only practice that makes skills a habit. Furthermore other evidence has shown that "modern training concepts", industrial learning (TEFA) and knowledge transfer schemes, can contribute to improving the performance of manufacturing innovations in Europe [16]. Therefore according to [17] that a new approach (TEFA) is very necessary in order to: (1) modernize the learning process closer to industrial practice; (2) utilizing industry practices to obtain new knowledge; (3) supporting the transition from labor-based and capitalbased manufacturing to information and knowledge-based manufacturing; and (4) developing and maintaining more stable industrial growth. The main objective of TEFA is to integrate education, research, and innovation activities into one initiative involving industry and academia effectively and efficiently. In that context, [16] further emphasize that modern training concepts, which are tangible industrial learning (TEFA) and knowledge transfer schemes, contribute to improving the performance of manufacturing innovations in European countries.

Still how far will the application of TEFA be able to contribute to the economic development of a country? There are several researchers who report this. At least in the last decade, the concept of TEFA has received important attention, especially in the United States, which has produced a number of educational and / or business pilot activities [18]. Industrial projects that take place at TEFA provide students with learning experiences that are integrated 
into contextual settings, where learning emphasis is given to competency and effective application. According to [19], most of the applications of the industrial learning paradigm are reported, simulating key features of the industrial environment in academic settings, using the equipment of production models. It should be noted that there are several studies that reveal the relationship between the quality of education and economic growth. Highlighting the fact that human resources are the key to economic growth [18], and according to Tether et al. (2005), that performance on international student achievement tests has a strong impact on economic growth, and therefore lack of skills will have a negative effect on innovation performance [18]. Furthermore, how far has the TEFA model been implemented properly? [20] reported the results of her research entitled "Evaluation of teaching factory at industrial vocational high school education and training center of ministry of industry" conducted by the CIPP method found that: (1) evaluation of the needs of the TEFA program was in "good" category; (2) evaluation of the preparation of the TEFA program is in the "right" category; (3) the assessment of the implementation of the TEFA program is in the "good" category; (4) evaluation of the results and benefits of the TEFA program in a "satisfying" position; and (5) the results and benefits of the TEFA program only benefit students, but have not been felt by stakeholders in the business world and the industry in general. The results of this study reminded the implementers of the TEFA program that it was necessary to improve the management of TEFA, so that the implementation of TEFA would not only benefit students but also benefit the industry in general. An effort to maintain the usefulness of TEFA for both parties will ensure the continuity of TEFA implementation better.

There are still a number of studies on the implementation of TEFA, both concerning the advantages and disadvantages. Lestari (2014) through a study entitled "Effectiveness of the implementation of TEFA of Vocational students in Solo Technopark Surakarta" found that there were several aspects of the strength of TEFA implementation, namely aspects of planning, implementation, management and evaluation processes and documentation activities that had been managed well. While the weaknesses of the implementation of TEFA include aspects of delay in the production of goods / services, due to lack of facilities and the number of new instructors filled as much as $50 \%$ of what should be. In contrast to the findings of Lestari (2014) and Fajaryati (2012) who concluded that in terms of learning activities, and the implementation of TEFA had gone well, while the activities of the production process had not been as smooth as expected. Therefore Fajaryati (2012) suggests several things: (1) socialization of TEFA learning needs to be done, both in schools, parents, and the community; (2) dissemination of TEFA learning in the educational, industrial and community environment so that the implementation of TEFA has broad support from various parties; (3) periodic evaluation and improvement of TEFA learning needs to be done; (4) need to increase capacity in conducting market research for TEFA teachers and managers; (5) need to improve marketing strategies for TEFA teachers and managers; (6) the need to develop market networks and distribution of TEFA products; and (7) need to increase the promotion of TEFA results in the wider community in a sustainable manner.

To improve TVET and TEFA's performance better, the following are suggested: (1) TEFA learning needs to be integrated with discovery learning, problem based learning, and project based learning models, in order to improve personal life skills that include personal skills, social skills, academic skills, and vocational skills that are characterized by entrepreneurial values that are independent, creative, innovative, risk-taking, oriented to action, leadership, hard work and competitiveness; (2) in general quality assurance (QA) in the TVET environment still needs to be improved, especially in Nigeria or other developing countries, because TVET is proven to have an impact on the national development of the country 
concerned; (3) in the context of increasing TVET's strategic role, cooperation between vocational education and relevant stakeholders is needed, in order to create quality education including through the teaching factory to be important; (4) more adequate TVET funding is needed so that: (a) training and retraining of TVET teachers can be better done; (b) providing TVET facilities so that TVET programs can run smoothly; and (c) partnerships between the state and the private sector, are important strategies in the context of increasing the TVET program. The fifth suggestion is to improve TEFA management so that the implementation of TEFA will not only benefit students but also benefit the industry in general, where efforts to maintain the benefits of TEFA for both parties will ensure the continuity of TEFA better.

\section{Conclusion}

From the discussion of the results of the research as described above, the following research findings are obtained: (1) technology and vocational education (TVET), has been directed to prepare students to enter the world of work with the design of vocational education that emphasizes the mastery of competencies in accordance with industrial needs; (2) TVET has a main and key role in the social and economic development of a country; (3) TVET has an impact on technical progress, work feasibility and national economic development such as finance, access / participation, guarantee of the quality and relevance of programs to the needs of the country; (4) the impact of TVET in Nigeria has not been impressive because of quality assurance (QA) that has not run effectively at all levels of management; (5) TEFA is a combination of competency and production-based learning approaches, where the practical learning process carried out resembles a practical process in the real world of work by conducting activities for the production of goods or services in the school environment; (6) there is a significant influence on the application of the TEFA program to the work readiness of vocational students, where the application of TEFA contributes $34.6 \%$ to work readiness; (7) the application of TEFA is able to contribute to the economic development of a country, where in April 2013, in Europe alone manufactured products accounted for more than $28 \%$ of GDP, even though there was a recession; and (8) in general the implementation of TEFA is in the category of right, good and satisfying.

To improve TVET and TEFA's performance better, the following are suggested: (1) TEFA learning needs to be integrated with discovery learning, problem based learning, and project based learning models, in order to improve personal life skills that include personal skills, social skills, academic skills, and vocational skills that are characterized by entrepreneurial values with the characteristics of being independent, creative, innovative, risk-taking, oriented to action, leadership, hard work and competitiveness; (2) in general quality assurance (QA) in the TVET environment still needs to be improved, especially in Nigeria or other developing countries, because TVET is proven to have an impact on the national development of the country concerned; (3) in the context of increasing TVET's strategic role, cooperation between vocational education and relevant stakeholders is needed, in order to create quality education including through the teaching factory to be important; (4) more adequate TVET funding is needed so that: (a) training and retraining of TVET teachers can be better done; (b) providing TVET facilities so that TVET programs can run smoothly; and (c) partnerships between the state and the private sector, are important strategies in the context of increasing the TVET program. The fifth suggestion is to improve TEFA management so that the implementation of TEFA will not only benefit students but also benefit the industry in general, where efforts to maintain the benefits of TEFA on both parties will ensure the continuity of TEFA better. 


\section{Acknowledgment}

For help from various parties, this research can be completed. For this valuable opportunity, he expressed his gratitude to the Chancellor of the State University of Surabaya who gave the opportunity where this research could be carried out smoothly in accordance with the planned time schedule. Likewise, the lecturers of the Surabaya State University's postgraduate technology and vocational education program, as well as students who have been actively involved in this study, so that the research can be completed properly, many thanks.

\section{References}

[1] F. P. Hadlock, R. B. Harrist, R. S. Sharman, R. L. Deter, and S. K. Park, "Estimation of fetal weight with the use of head, body, and femur measurements-A prospective study," Am. J. Obstet. Gynecol., vol. 151, no. 3, pp. 333-337, Feb. 1985.

[2] S. B. Nasir, Strategy to revitalize technical and vocational education and training (TVET) management perspectives. USA: Publisher Global Journals Inc, 2012.

[3] C. A. Prosser and T. H. Quigley, Vocational Education in Democracy. Chicago: American Technical Society, 1950.

[4] I. Akhuemonkhan, R. Raim, and J. O. Dada, "Impact of quality assurance on technical vocational education and training in nigeria," Afro Asian J. Soc. Sci., vol. 5, no. 5, pp. $1-25,2014$.

[5] A. C. Shirley, O. P. Chijioke, and O. B. Chukwumaijem, "Challenges and Improvement Strategies," J. Educ. Learn., vol. 4, no. 1, 2015.

[6] M. B. R. Wijaya, "Model pengelolaan teaching factory di Sekolah Menengah Kejuruan," J. Penelit. Pendidik., vol. 30, no. 2, 2013.

[7] M. Nurtanto, S. D. Ramdani, and S. Nurhaji, "Pengembangan Model Teaching Factory Di Sekolah Kejuruan," in Prosiding Seminar Nasional Pendidikan FKIP, 2017, vol. 1.

[8] S. S. Dewi and P. Sudira, "The Contribution of Teaching Factory Program Implementation on Work Readiness of Vocational High School Students In Makassar," J. Educ. Sci. Technol., vol. 4, no. 2, pp. 126-131, Aug. 2018.

[9] S. Sharan, The handbook of cooperative learning Inovasi pembelajaran untuk memacu keberhasilan siswa di kelas. Yogyakarta: Familia (Grup Relasi Inti Media), 2012.

[10] E. B. Johnson, CTL-Contextual teaching \& learning. Bandung: Kaifa, 2014.

[11] S. Muslim, N. P. Gitama, B. Suprianto, E. Rahmadyanti, and N. Kusumawati, "Influence of learning media based on adobe flash professional to psychomotor domain learning outcomes on plc courses viewed from level of creative thinking student," J. Pendidik. Vokasi, vol. 8, no. 3, p. 267, Nov. 2018.

[12] S. Muslim, B. Suprianto, and N. Putra Gitama, "Development Module (Lab Report) As a Media of Learning in Vocational Education Viewed by Gender," IOP Conf. Ser. Mater. Sci. Eng., vol. 336, p. 12035, Apr. 2018.

[13] S. Muslim, "Tes Kinerja (performace test) dalam bidang pendidikan teknologi dan kejuruan," in Seminar Teknik Elektro dan Pendidikan Teknik Elektro, 2013.

[14] D. H. E. Pradana and S. Yoto, "Manajemen pelaksanaan teaching factory dalam mempersiapkan lulusan memasuki dunia kerja siswa SMK Muhamadiyah 7 Gondanglegi," Jupedasmen, vol. 4, no. 1, p. 97, 2018.

[15] E. M. Indrawati, "Peningkatan pencapaian kualitas lulusan D-3 Teknik Elektro dengan model teaching factory," J. Penjaminan Mutu, vol. 3, no. 1, pp. 43-52, 2017. 
[16] G. Chryssolouris, D. Mavrikios, and D. Mourtzis, "Manufacturing Systems: Skills \&amp; Competencies for the Future," Procedia CIRP, vol. 7, pp. 17-24, 2013.

[17] D. Mavrikios, N. Papakostas, D. Mourtzis, and G. Chryssolouris, "On industrial learning and training for the factories of the future: a conceptual, cognitive and technology framework," J. Intell. Manuf., vol. 24, no. 3, pp. 473-485, Jun. 2013.

[18] L. Rentzos, M. Doukas, D. Mavrikios, D. Mourtzis, and G. Chryssolouris, "Integrating Manufacturing Education with Industrial Practice Using Teaching Factory Paradigm: A Construction Equipment Application," Procedia CIRP, vol. 17, pp. 189-194, 2014.

[19] U. Wagner, T. AlGeddawy, H. ElMaraghy, and E. MŸller, "The State-of-the-Art and Prospects of Learning Factories," Procedia CIRP, vol. 3, pp. 109-114, 2012.

[20] Lucyana, B. Tunas, and W. Sunaryo, "Evaluation of teaching program at industrial vocational high school of industrial education and training center ministry of industry," Int. J. Innov. Res. Sci. Technol., vol. 6, no. 9, pp. 17851-17856, 2017. 